International Journal of Social Sciences and Humanities
Available online at http://sciencescholar.us/journal/index.php/ijssh
Vol. 2 No. 2, August 2018, pages: $252 \sim 264$
e-ISSN: 2550-7001, p-ISSN: 2550-701X
https://doi.org/10.29332/ijssh.v2n2.166

\title{
Dam Construction Analysis in Indonesia: A Public Policy View
}

Dessy Lay a ${ }^{\text {a }}$ Alo Liliweri ${ }^{\mathrm{b}}$, Ajis Salim Adang Djaha ${ }^{\mathrm{c}}$
Article history: Received 5 April 2018, Accepted in revised form 12 July 2018, Approved 10 August 2018,
Available online 23 August 2018

a Public Administration Faculty, Postgraduate Program, Universitas Nusa Cendana, Kupang, Indonesia; Civil Servant of Kupang City Government, Indonesia

b Public Administration Faculty, Postgraduate Program, Universitas Nusa Cendana, Kupang, Indonesia

c Public Administration Faculty, Postgraduate Program, Universitas Nusa Cendana, Kupang, Indonesia 
3.4 Analysis

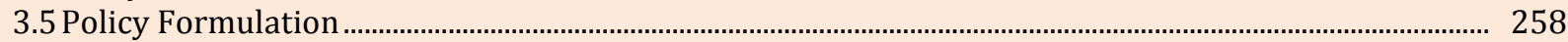

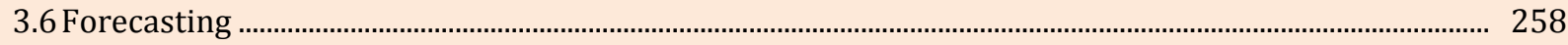

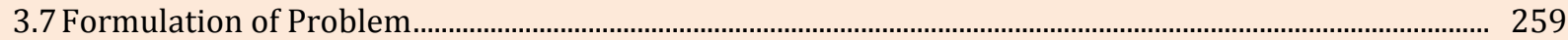

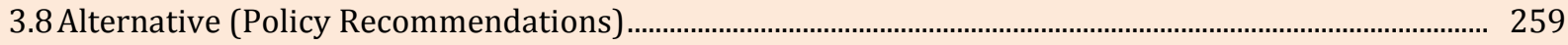

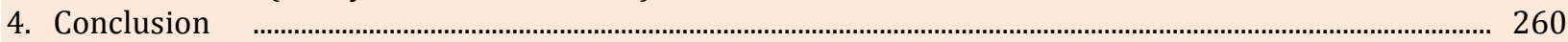

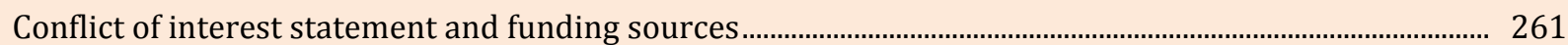

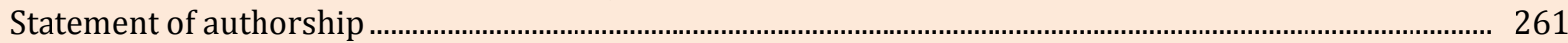

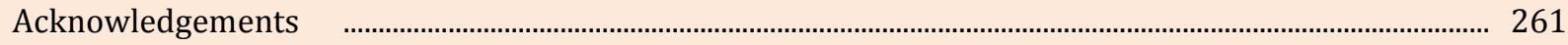

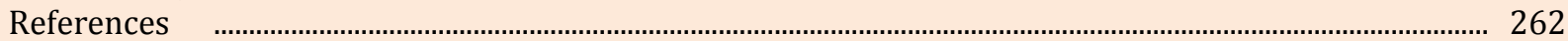

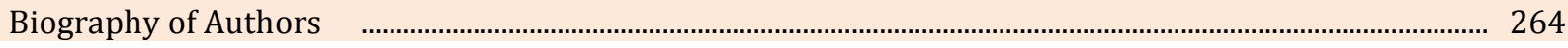

\section{Introduction}

There is no development that does not involve the environment, both physical and social environment. This means the approach to the nature of the construction is a mix of economic and social aspect (Soemarwoto, in Suwartapradja, 2005:1). Physically, it consists of land that has been the object of the population lives, while socially, it consists of a population that has to move due to the displaced. One development that carried out, related to what has been stated, was the construction of a dam. The construction of the dam contains some objectives, such as for irrigation in the development of the agricultural sector, for power plant water (Hydropower), for tourism, for water supply, and for flood control (Soemarwoto, 1999). This research was focused on the dam construction in Kupang city. Kupang city, as one of the cities in Indonesia, has faced a high rank of clean water needs. In other words, Kupang city is a dry place in Indonesia.

The Government, through the Mayor of Kupang city, had planned the dam development programs to address the problem of clean water in Kupang city. Based on the Government design, the dam would be built on land that is located in the Kolhua, Kupang. Based on the initial plan, the dam would be called Kolhua dam. Nevertheless, the construction of Kolhua dam that considered as solutions to overcome the clean water problem for Kupang citizen was still being debated. It has been prolonged polemics. Currently, in the year 2018, the dam cannot be built since people around the location rejected the plan (Mardika: 2017).

Noticing a gap between das sollen, i.e. what is expected and das sein, i.e. fact has happened, on the construction of the Kolhua dam, the researcher stated that the phenomena required a scientific review of its implementation. Such studies should refer to a legal product in the form of policy. In addition, the existence of a gap between the das sollen and das sein, this research has a high value for the meaningfulness of human life in the world, in this case for the Indonesia community, especially for Kupang City. As already stated previously, construction of Kolhua dam was intended to address the problem clean water in the city of Kupang. If the conflict of Kolhua dam project is resolved then the main problem of life, namely the availability of drinking water for the community of Kupang citizen will be handled as well. This certainly gives a great contribution to society. That is why this research was conducted, namely to reveal the development policy of Kupang city Government related to dam construction project in the Kupang city, and to reveal factors that caused conflict between the government and Kupang citizens, therefore the policy was rejected (Sholahuddin, et al.: 2018).

\section{Research Method}

This study used qualitative methods. The approach applied was the descriptive approach. The purpose of qualitative research is to understand the situation, event, group or specific social interaction (Locke, Spirduso \& Silverman, 1987), in (Creswell 2014:292). This research can be defined as the process of investigative which researcher interpret social phenomena gradually with a differentiating, comparing, copying, analogizing, and classifying objects (Miles \& Huberman, 1984). In this study, the researcher conducted the investigation on two objects of research, namely, on the government and citizen. On the Government, the researcher identified the

Lay, D. (2018). Dam construction analysis in Indonesia. International Journal of Social Sciences and Humanities, 2(2), 252-264. https://doi.org/10.29332/ijssh.v2n2.166 
model formulation and implementation of the policy of Kolhua dam development. While from the community, the researcher investigated citizens' response to the policy (Basak, et al.: 2017).

\section{Research Focus} below.

Important aspects were focused on the research of Dam Kolhua project analysis is described in table 1

Table 1

Research Focus

\begin{tabular}{lll}
\hline No. The Focus of The Research & \multicolumn{1}{c}{ The Focus of The Research } \\
\hline 1. Policy Formulation & 1. Formulation of The Problem \\
& 2. Forecasting \\
2. Impact & 3. Policy Alternatives \\
& 1. Accepted \\
& 2. Rejected
\end{tabular}

This research was conducted at Kupang City, especially in Kolhua sub-district. As stated previously, Kupang city is a city in Indonesia.

Data collection techniques used in this research were documentation, structured interviews, and unstructured interviews. In a structured interview, the researcher interviewed Mayor of Kupang City, Chairman of the Kupang City Parliament and Chairman of East Nusa Tenggara Province Parliament. The aim of the interviews was to gain complementary information related to the scientific problems discussed here. The unstructured interviews were conducted for Kupang citizens. At this point, the researcher interviewed customary figures and public figures, to know citizens response of the Policy of Kolhua dam project. Using documentation technique, the researcher gained data from another interview result that published in local newspaper. In the validation of research results, the techniques used was triangulation (Creswell \& Milles, 2000).

The research process was divided into four major activities namely (1) Data Collection (2) Data condensation, (3) Data display, and (4) Conclusion. Those four activities can be seen in figure 1 below.

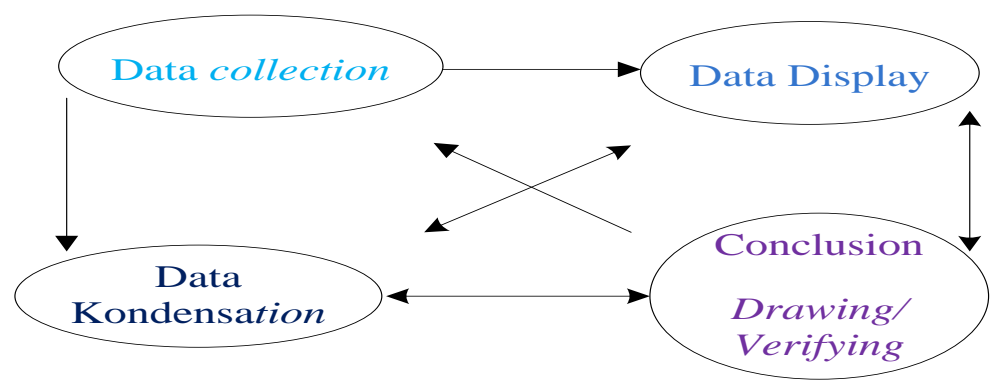

Figure 1. Research Process

Source: Miles, M.B. \& Huberman, A.M. 1994.

Furthermore, the exposure of data analysis was displayed based on Dunn's analysis mode (Dunn; 2000, 25). The mode can be seen in figure 2 below. 


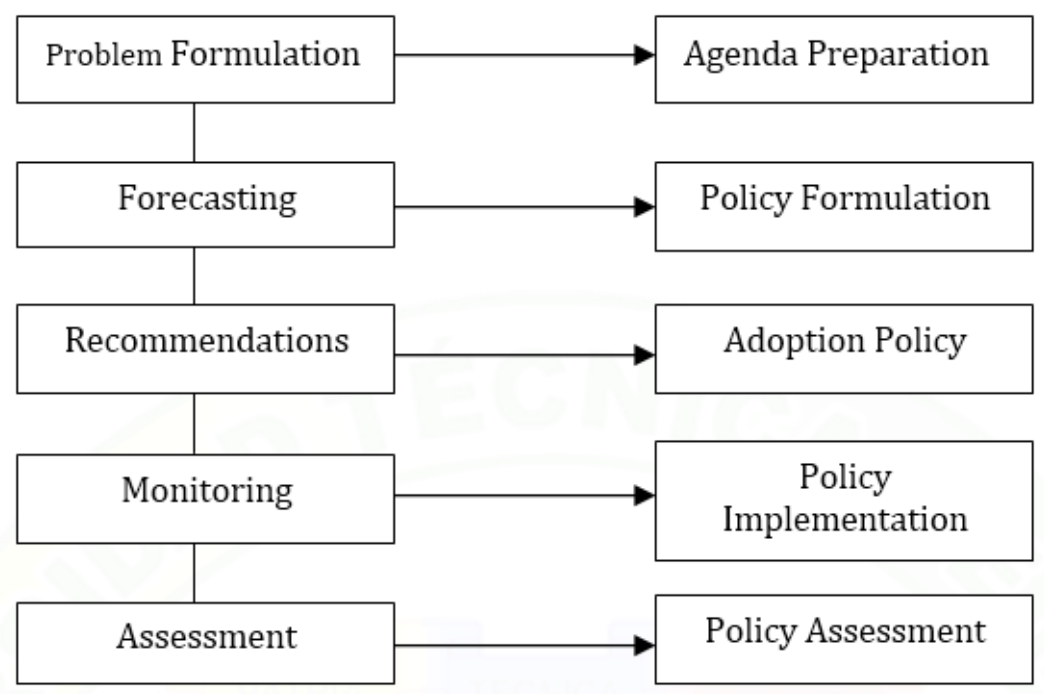

Figure 2. Dunn's Analysis Mode Source: Dunn (2000: 25)

\section{Results and Analysis}

In this section, the researcher presents a scientific discussion that based on the basic theory and the data gained. The structure of the discussion will be displayed as follows. Firstly, the researcher describes a brief explanation about Kolhua Dam. After that, she will describe the public policy of building Kolhua Dam. The description will be followed by an explanation of the policy process and policy formulation. Finally, as parts of policy formulation, there will also be discussed forecasting, formulation of the problem, and alternative or policy recommendations.

\subsection{Kolhua Dam}

Kolhua Dam, as planned by Kupang city government, would be located in Kolhua, Kupang city. Kupang is the only city in the Government of East Nusa Tenggara Province (an eastern province in Indonesia) and has become the capital of the province. The provincial capital is located at NTT $10^{\circ} 36^{\prime} 14^{\prime \prime}-10^{\circ} 39$ ' 58" LS and $123^{\circ} 32^{\prime} 23^{\prime \prime} 123^{\circ} 37^{\prime} 01^{\prime \prime} \mathrm{E}$ with an area of $180.27 \mathrm{Km} 2$. The average temperature in the Kupang city ranged from $23.8^{\circ} \mathrm{C}$ up to $31.6^{\circ} \mathrm{C}$. An average air humidity ranging between 73 percent up to 99 percent of (Kota Kupang dalam angka, 2010). An area of Kupang is $180.27 \mathrm{~km}^{2}$ with a population of approximately 450,000 people. The population growth average was 3.53\% (BPS, 2012). Kupang is divided into 6 districts and 50 villages. One of the urban villages is Kolhua. Following figure (3) is the location of Kolhua, which located in East Nusa Tenggara- Indonesia.

Lay, D. (2018). Dam construction analysis in Indonesia. International Journal of Social Sciences and Humanities, 2(2), 252-264. https://doi.org/10.29332/ijssh.v2n2.166 


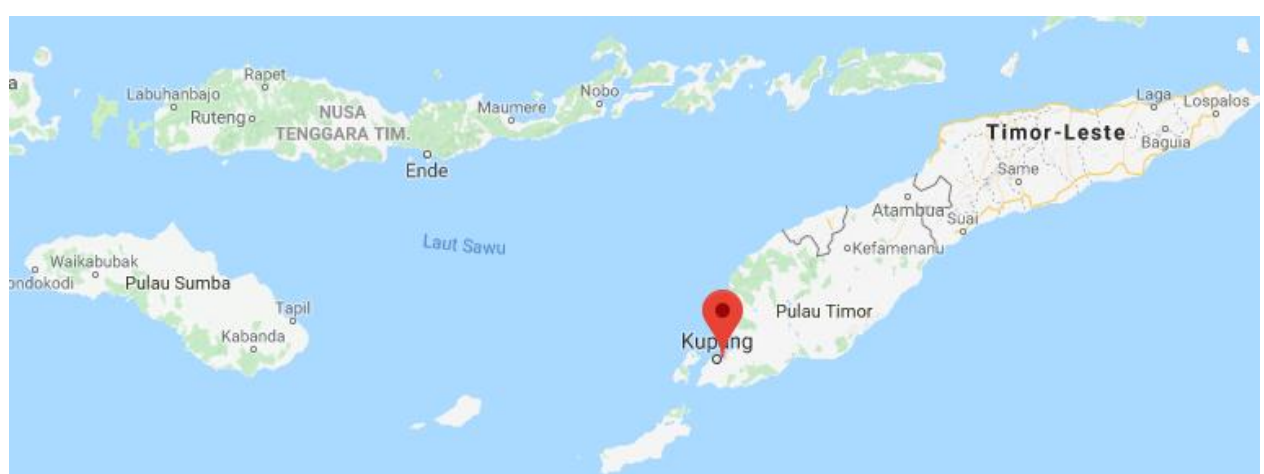

Figure 3. East Nusa Tenggara Province- Indonesia Source: (Google Map)

\subsection{Public Policy of building Kolhua Dam}

To build Kolhua Dam was a public policy of Kupang City government. The definition of public policy proposed firstly by Harold Laswell and Abraham Kaplan in Howlett and Ramesh (1995:2). They defined public policy as a projected of goals, values, and practices. A similar statement was defined by George C. Edwards III and Ira Sharkansky in Suwitri (2008: 10)

defined public policy as 'an act of the Government in the form of government programs for the achievement of the goals or objectives'. In other words, the development policy of Kolhua dam was a project to achieve a target. Kolhua dam development planned by Government of Kupang city aimed to overcome the problem of drinking water in Kupang city.

Thomas R. Dye in Howlett and Ramesh (2005:2), on the other hand, defined public policy as what governments do, why they do it, and what differences it makes (cf. Tilaar and Dwijowijoto, 2008:185; Subarsono, 2005: 2. In the process of making public policy for building Kolhua dam, point one about 'what government did', and two points about 'why they do', were clear enough. Kupang city government wanted to build a dam for giving a solution for the need of clean water faced by Kupang citizen. Unfortunately, the third point about 'what differences it makes' did not meet the theory stated above. Based on the data, the dam could not be built for there were some conflicts about the policy.

According to Thomas R. Dye in Dunn (2000: 110), there are three policy elements that form the system of policy. Dye described three elements of the policy as public policy, policy stakeholders, and policy environment. Those elements can be seen in figure 4 below.

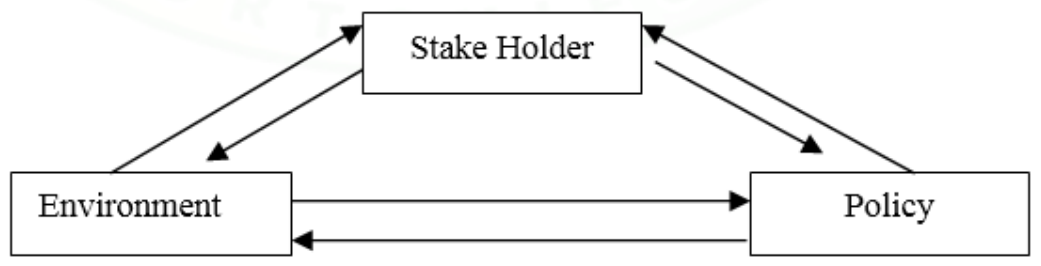

Figure 4. Three elements of policy

Source: Thomas R. Dye in Dunn (2000:110)

As proposed by Dye that can be seen in figure 4, Kupang city government was the stakeholder. The environment was people in Kolhua, while the policy was building a dam. However, since there was a conflict that caused environment rejected the dam building policy, as has been stated, currently, the dam could not be built. Therefore, the researcher conducted further analysis, especially on the process of how stakeholder made the policy. 


\subsection{Policy Process}

If the policy can be viewed as a system, then the policy can also be viewed as a process. In the policy process, Nugroho stated that most classic policy process theory was proposed by Easton (1985). Easton in Nugroho (2008: 383) explained that the policy process may be analogous with biological systems. Basically, the biological system is the process of interaction between living beings and their environment, which finally creates a continuity stable life changes. In the terminology of this point, Easton analogized it with the process of the political system. Public policy, as a part of the political system, with a model of the system, presupposes that policy itself is the result or output, as can be seen from Figure 5 below.

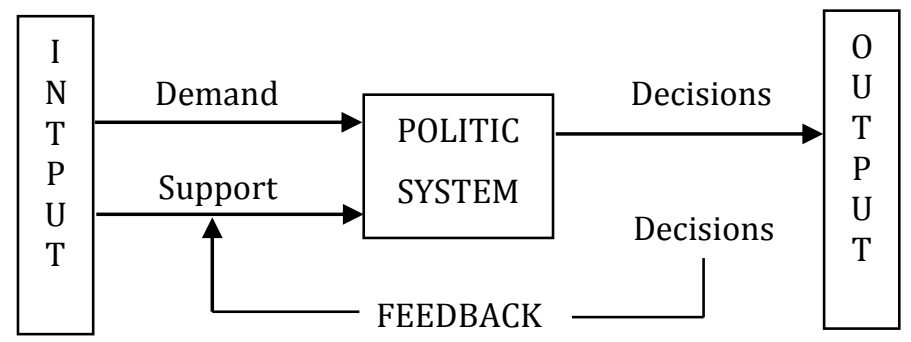

Figure 5.

Source: David Easton in Nugroho (2008:383)

A process model of public policy that proposed by Easton (2008) assumed the public policy process in the political system by relying on the input in the form of demand and support. At this level, the research on the analysis of Kolhua dam project has become more important since it contains demand but has no support. Kupang citizen and the problems of the availability of clean water was the ' input '. Kupang city government was in 'politic system' scheme. The government made decisions or policy to have an output. The output was to build Kolhua dam. Unfortunately, the output could not be reached as there was a conflict between policy and support.

Liliweri (2005:249) stated conflict as scientific dispute forms that generated by individuals or groups, because of the differences in attitudes, beliefs, values, and needs. Based on the statement, the researcher started to do an introductory analysis, that Kupang Citizen had a different attitude, different belief system, and different value. This introductory analysis will be deepened with following further analysis.

\subsection{Analysis}

Following is a figure from the documentation data when the demonstration was held to reject government policy.

Lay, D. (2018). Dam construction analysis in Indonesia. International Journal of Social Sciences and Humanities, 2(2), 252-264. https://doi.org/10.29332/ijssh.v2n2.166 


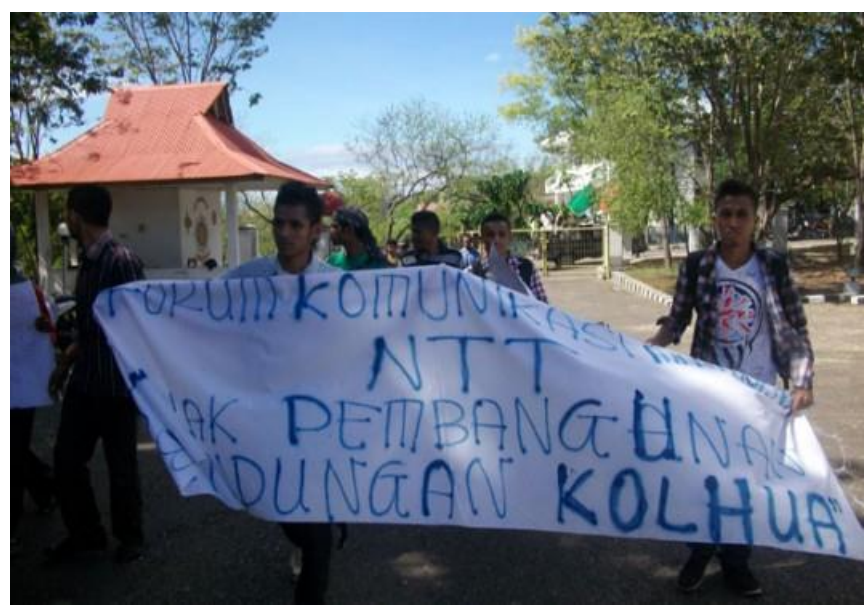

Figure 6. Rejection of government policy

Source: (Kupang Tribun News)

In a further section, the researcher presents her analysis of why people around location rejected the public policy of Kupang city government. The analysis was started by an explanation of policy formulation, forecasting, formulation of the problem, and alternative/ recommendation.

\subsection{Policy Formulation}

In policy formulation, there is a step of analysis about what is supposed to do, namely forecasting. Issues that have been inputted into the policy agenda later will be discussed by policymakers. The issues are discussed to get the best solution. The solutions come from a variety of policy alternatives or policy options. In the policy formulation, each policy alternative will compete to be selected as a policy taken to solve problems/ issues. In this stage, each actor will be competing and do its best to propose the best solution.

\subsection{Forecasting}

Dunn explained: Forecasting can test future plausible, potential, and valuable, in order to estimate a result of the policies proposed, recognizing the constraints, which will probably happen in the achievement of objectives, and to estimate political feasibility (support and opposition) of the choices. Based on interview data, there were some forecasting conducted. They were forecasting from the government side and forecasting from Kupang citizen side.

First, from the side of Kupang city government, they have made forecasting. The forecasting they made were: 1) If the clean water problem was not be overcome, Kupang citizen would have more social problems. Therefore, they decided to build a dam. 2) The dam would be built in Kolhua since this was the best place in Kupang city for building a dam.

As the researcher conducted a deeper interview to Kupang city government about the potential of negative impact in the future, generally, the Government have recognized that there will be the negative impact of the dam project. Unfortunately, the Government did not convene a follow-up approach related to the forecasting problem.

Second, from the side of Kupang citizen, there were some forecasting made as well. Results of interviews with various parties indicated that based on their forecasting, some problems and conflicts would appear if the policy of dam project is kept conducted. First, unemployment case will arise. This will happen since the land which Kolhua dam will be built was agricultural land. If the land functions were shifted, a lot of unemployment will be risen. Second, poverty will occur. This will be happened since the land price, which will be repaid by Government, was not comply to the land price in General. In other words, the people who owned the land will experience economic losses. Third, the cultural shock will be happened since the land that dam is going to be built belonged to their ancestors. Based on the cultural value, ancestors land must not be sold in 
any condition. Following figure (figure 7) shows a photo of a citizen when he pointed his ancestors' land, where Kolhua dam project would be built.

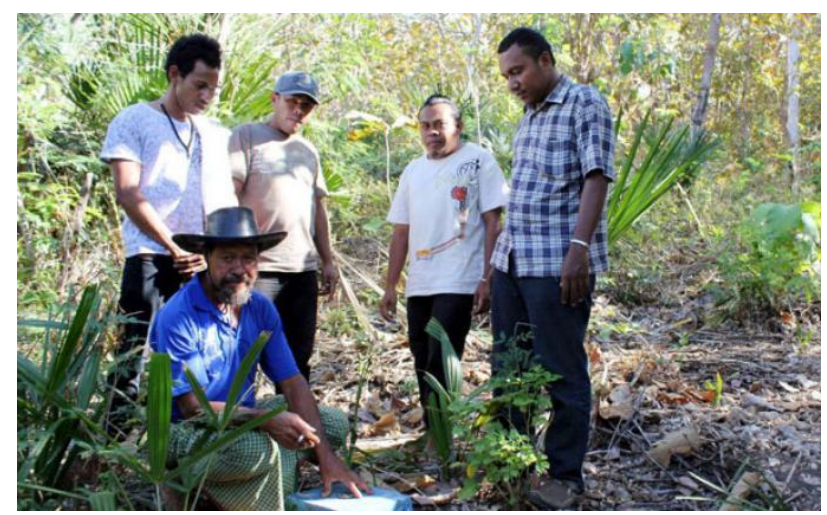

Figure 7. A citizen (man with a black hat) pointed to his ancestors' land Source: (Kupang Tribun News)

\subsection{Formulation of Problem}

Formulation of the problem must be based on more than a single thing. One thing that must be used as basic, is the problem itself. Issues that have been inputted into the policy agenda later will be discussed by policymakers. The issues are discussed to get the best solution. The solutions come from a variety of policy alternatives or policy options. Based on the interview, there was a problem of clean water in Kupang city.

Interviews that conducted towards the research respondents (resource persons), related to Kolhua dam project policy formulation, showed results as follows. The policy of Kolhua dam project was initiated based on the background of clean water problems in Kupang city. This can be known by examining the growing issues and facts that Kupang city needs a dam to overcome water availability in Kupang city.

Kupang City Government stated that the issue of clean water in Kupang citizen needs an alternative solution. The alternative of overcoming the clean water problem in Kupang city is by building dams/reservoirs. Based on interviewed data, the alternative was decided by building a viable approach. After that, the alternative of overcoming clean water problem in Kupang city was made as a government policy.

While the community in Kupang city itself, in principle, agreed with the alternative of dams/reservoirs building project because it concerned with the Kupang citizen interests. However, as revealed by interview result, Kupang citizens stated that the government has never discussed their plans in a forum (Construction Plans Discussion).

In other side, Kupang citizens, especially people around Kolhua, as has been mentioned previously, rejected the policy since the land where the dam would be built was their ancestors' heritage. It was the only land for them to do farming for a living. Relate to the alternative of Kolhua dam project, citizens stated that the water source in Kolhua was not the only water source that can be used by Kupang government. Citizens noted, there are at least 25 potential spring points, which were not managed by Government of Kupang city. At this point, the researcher found a miscommunication phenomenon between government and citizen.

\subsection{Alternative (Policy Recommendations)}

Based on an interview conducted by the researcher, Kupang city government had only a single policy recommendation, which was to keep building a dam. This would be a good solution for overcoming clean water problem. However, based on the interview about forecasting that has been described above, there were still another problems and conflicts because of the policy. In this point, there should be an alternative for the problems.

When the researcher interviewed Kupang City Major, it was found that The Major did not want to listen to what people around location said. The major pushed his will without considering the forecasting of people. He

Lay, D. (2018). Dam construction analysis in Indonesia. International Journal of Social Sciences and Humanities, 2(2), 252-264. https://doi.org/10.29332/ijssh.v2n2.166 
said, what he has decided is for Kupang citizen's needs. He kept asking people to understand that the policy about dam location is the best location. At this point, more conflict was created.

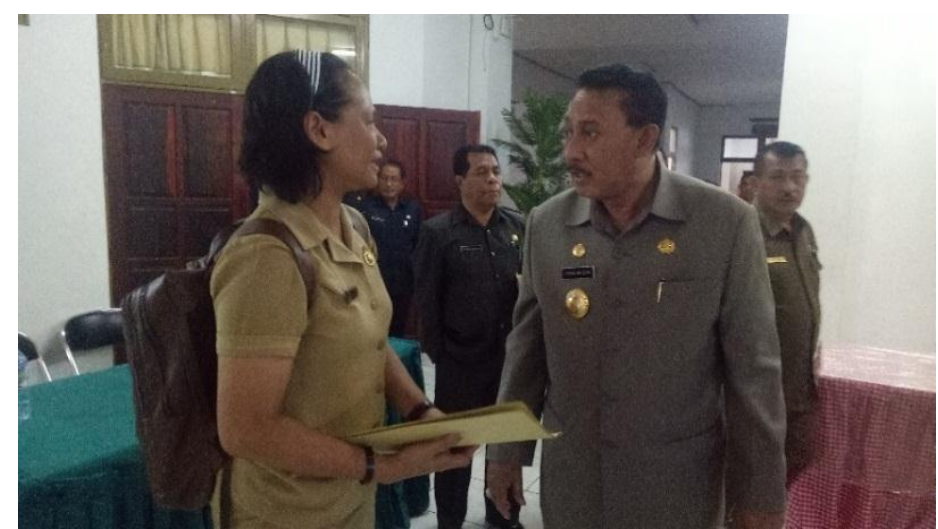

Figure 8. On an interview with Kupang City Mayor Source: Researcher Documentation

In another side, the citizen of Kupang, especially people around Kolhua area asked another alternative for the policy. Getting back to the previous introductory analysis stated by the researcher, the different attitude and different belief systems between government and citizen existed. Based on interviews, the main problem that caused conflict was the land in which a dam would be built. About the land, the government stated that the land would be paid back at a high price. Furthermore, another land would be given to the people, so they would be able to keep working as farmers. Unfortunately, based on the interview, the researcher found that people around the land did not trust what the government said. They stated that the government would easily forget promises. Also, ' high standard ' price stated by the government was still low in Kupang citizen standard.

Furthermore, the Kupang citizen, especially people around Kolhua area recommended their government to find another location as another alternative. They have agreed that the solution to clean water problem must be found and a dam must be built, but they wanted the government to listen to their suggestions related to the land where the dam will be built. However, the government, in this case, Kupang City Major, as has been stated above, was still in his decision. As the results, up to the year, this research is about to be published, in 2018, the policy of dam project cannot be realized.

\section{Conclusion}

Kolhua dam project was an appropriate alternative to solve problems of clean water needs in Kupang city, Indonesia. The alternative policy that has been set by the Kupang city government, based on this research, was also appropriate. Related to facts that the policy plan was rejected, herewith stated some scientific conclusions and recommendations.

The conclusions, based on the discussion above, are as follows. First, the policy formulations applied by Kupang city government were: 1) examining conditions and issues of the clean water needs, 2) deciding alternative solution, 3) deciding to build a dam in Kolhua area, 4) shifting the decision into Kupang City Policy, 5) socializing the policy to Kupang citizens. Second, the policy rejection by citizens was caused by 1) in the policy-making process, especially before policy statement, Kupang government did not do democracy approach. The government, based on citizens point of view, used authority approach. Therefore conflict was created. In other words, the government used the Top-Down approach, not Down-Top approach. 2) The land, where the dam project would be built in, was citizens ancestors' heritage. Based on the cultural value of local people, ancestors' heritage must not be sold, in any condition. In other words, there will be cultural shocked. 3) The land, where the dam project would be built in, was a place for farming. It was the place where citizens work to get a life. 4) There were also ancestors' graves on the land. 5) The government would not pay a good 
price. The clue of those conclusions is: policy of Kupang City government was rejected because of the weakness of government social approach system itself.

Some points, based on the conclusions made, are suggested as follows. First, government should do better social approach before stating a policy, especially the policy of dam location. The government is supposed to examine many aspects such as social aspects, economic aspects, as well as cultural aspects. Second, the government should pay the land back with the appropriate value and should show that government can be trusted in giving new land for farming. Third, the government should remove the graves that have been in the location for many years. Fourth, if those three suggestions cannot be fulfilled, the government could choose another location to build the dam since other locations are also available in Kupang city.

Conflict of interest statement and funding sources

The author declared that she has no competing interest. The study was financed by herself.

Statement of authorship

The author has a responsibility for the conception and design of the study. The author has approved the final article.

\section{Acknowledgments}

The author would like to thank Prof. Liliweri who has helped the author with a lot of suggestions, especially when the author studied in Master Program of Undana university.

Lay, D. (2018). Dam construction analysis in Indonesia. International Journal of Social Sciences and Humanities, 2(2), 252-264. https://doi.org/10.29332/ijssh.v2n2.166 


\section{References}

1. Basak, A., \& Khanna, K. (2017). A Study on the Selection Criteria of Different Hotels of Delhi NCR in Accordance to the HR Policies and Market Trends. International Journal of Social Sciences and Humanities (IJSSH), 1(1), 27-38.

View in (Google Scholar)

2. Creswell, J. W. (2014). A concise introduction to mixed methods research. Sage Publications. View in (Google Scholar)

3. Creswell, J. W., \& Miller, D. L. (2000). Determining validity in qualitative inquiry. Theory into practice, 39(3), 124-130.

View in (Google Scholar)

4. Dunn, W. N. (2000). Analisis Kebijakan Publik. Edisi Kedua. Yogyakarta: Terjemahan Samodra Wibawa dkk. View in (Google Scholar)

5. Easton, D. (1985). Political science in the United States: Past and present. International Political Science Review, 6(1), 133-152.

View in (Google Scholar)

6. Howlett, M., Ramesh, M., \& Perl, A. (2009). Studying public policy: Policy cycles and policy subsystems (Vol. 3). Oxford: Oxford University Press.

View in (Google Scholar)

7. Liliweri, A. (2005). Prasangka dan Konflik; Komunikasi Lintas Budaya Masyarakat Multikultur. LKIS PELANGI AKSARA.

View in (Google Scholar)

8. Locke, L. F., Spirduso, W. W., \& Silverman, S. J. (1987). Proposals that Work. Newbury Park. CA: Sage Publications, 112-115.

View in (Google Scholar)

9. Mardika, I. N. (2017). Opposition of Community Citizenship Against the Policy of the Village's Leader. International Journal of Social Sciences and Humanities, 1(3), 74-87.

View in (Google Scholar)

10. Miles, M. B., \& Huberman, A. M. (1984). Drawing valid meaning from qualitative data: Toward a shared craft. Educational researcher, 13(5), 20-30.

View in (Google Scholar)

11. Nugroho, R. (2008). Public Policy, Teori Kebijakan-Analisis Kebijakan-Proses Kebijakan, Perumusan, Implementasi, Evaluasi, Revisi Risk Management dalam Kebijakan Publik, Kebijakan sebagai The Fifth Estate-Metode Penelitian Kebijakan. Dalam: Kebijakan Publik, Kebijakan sebagai The Fifth Estate-Metode Penelitian Kebijakan. Jakarta: Elex Media Komputindo, Kelompok Gramedia.

View in (Google Scholar)

12.Sholahuddin, A., \& Sadhana, K. (2018). Policy implementation of nazhir endowments. International Research Journal of Engineering, IT and Scientific Research (IRJEIS), 4(2), 63-72.

View in (Google Scholar)

13. Soemarwoto, O. (1999). Analisis mengenai dampak lingkungan. Gajah Mada University Press. View in (Google Scholar) 
14. Subarsono, A. G. (2005). Analisis kebijakan publik: konsep, teori dan aplikasi. Pustaka Pelajar. View in (Google Scholar)

15. Suwartapradja, O. S. (2005). Konflik Sosial (Kasus Pada Pembangunan Bendungan Waduk Jatigede di Kabupaten Sumedang Jawa Barat). Abstrak.

View in (Google Scholar)

16. Suwitri, S. (2008). Jejaring Kebijakan Dalam Perumusan Kebijakan Publik Suatu Kajian Tentang Perumusan Kebijakan Penanggulangan Banjir Dan Rob Pemerintah Kota Semarang. Jurnal Delegasi, Jurnal Ilmu Administrasi, STIA Banjarmasin, 6(3), 01-32.

View in (Google Scholar)

17. Tilaar, H. A. R., \& Dwijowijoto, R. N. (2008). Kebijakan pendidikan: Pengantar untuk memahami kebijakan pendidikan dan kebijakan pendidikan sebagai kebijakan publik. Pustaka Pelajar.

View in (Google Scholar)

Lay, D. (2018). Dam construction analysis in Indonesia. International Journal of Social Sciences and Humanities, 2(2), 252-264. https://doi.org/10.29332/ijssh.v2n2.166 


\section{Biography of Author}

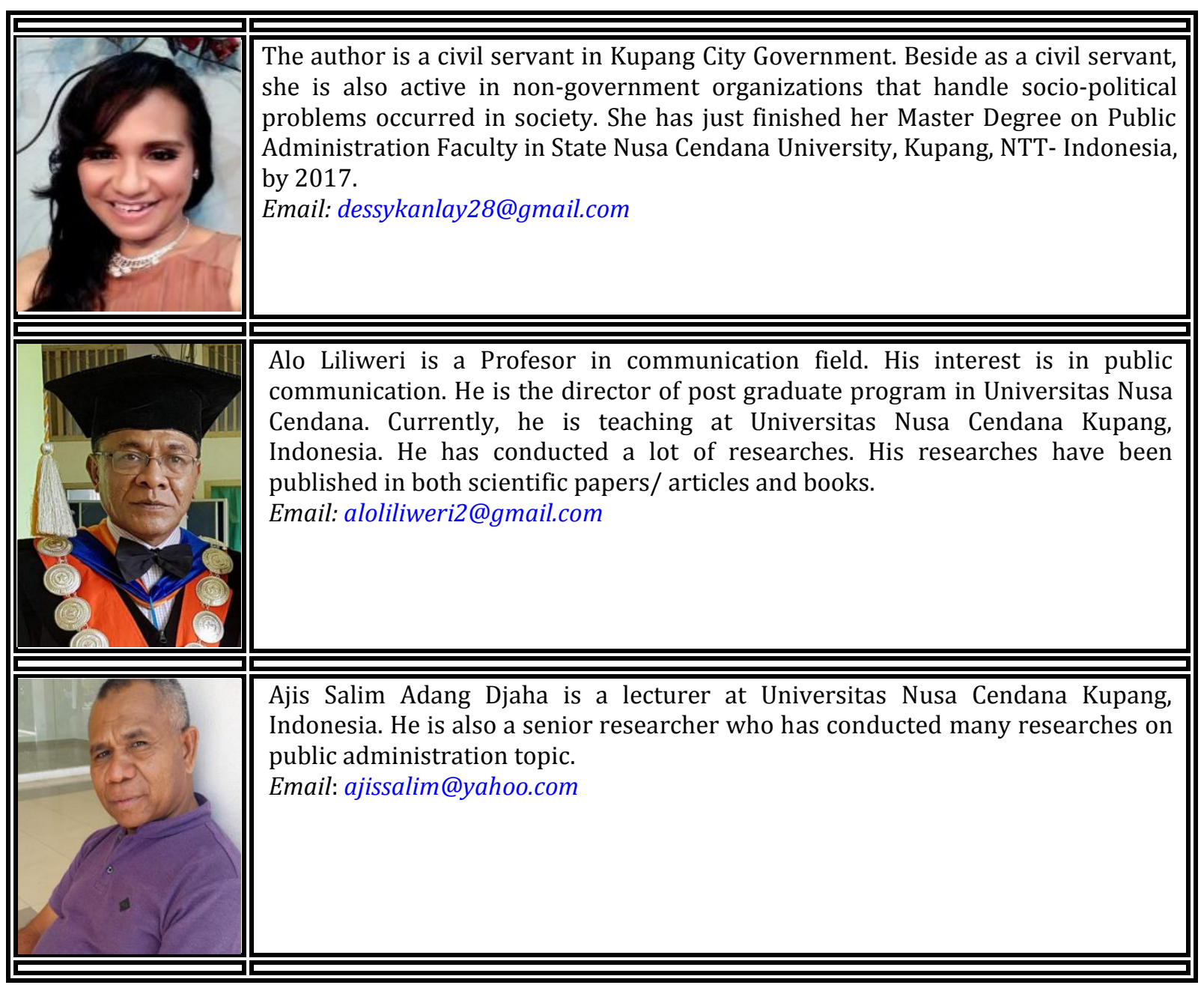

